\title{
STATUS OF THE CALIFORNIA GNATCATCHER AT THE NORTHERN EDGE OF ITS RANGE
}

\author{
DANIEL S. COOPER, Cooper Ecological Monitoring, Inc., 255 Satinwood Ave., \\ Oak Park, California 91377; dan@cooperecological.com \\ JENNIFER MONGOLO, Streamscape Environmental, 5042 Wilshire Blvd. \\ \#33273, Los Angeles, California 90036; jen@mapecology.com
}

CHRIS DELLITH, U.S. Fish and Wildlife Service, 2493 Portola Road Suite B,

Ventura, California 93003; chris_dellith@fws.gov

\begin{abstract}
At the northern edge of its range, the California Gnatcatcher has long been known to occur from eastern Ventura County east into northwestern Los Angeles County, but the current status of birds in these areas is not well understood. We review historical and recent sources of information and draw two main conclusions: first, that the California Gnatcatcher population that once existed from the lower Santa Clara River Valley in Ventura County east/upstream to Santa Paula and Simi Valley has likely contracted to the southeast. Second, that the current, consistent range of the species in Los Angeles County does not extend north of the San Gabriel Valley. The California Gnatcatcher is evidently extirpated from the San Fernando Valley and never occurred regularly in the Santa Clarita area to the northwest. Dispersing and even occasionally nesting birds in northwestern Los Angeles County have not resulted in a stable, consistent population there. Misinterpretation of seasonal movements and isolated sightings of the California Gnatcatcher here may have led to a misunderstanding of the boundaries of its normal range, as well as the misapplication of critical habitat as defined under the Endangered Species Act. As a result, we recommend that immediate conservation efforts be focused in areas where birds are conclusively known to occur, namely, the Thousand Oaks/Moorpark area of Ventura County, and that coastal sage scrub at low elevations in the Santa Clarita and especially the northeastern San Fernando Valley areas of Los Angeles County be systematically searched to locate any remaining populations.
\end{abstract}

The California Gnatcatcher (Polioptila californica), resident from southwestern California to Baja California Sur, Mexico, has been the subject of research and conservation efforts for more than 35 years (e.g., Rotenberry and Scott 1998). It occurs consistently in larger patches of low-elevation ( $<1500$ feet) coastal sage scrub along the immediate coast and in coastal valleys south of the Los Angeles area into Baja California (Atwood and Bontrager 2001). However, at more interior (eastern) sites and the northern end of its range, its distribution becomes patchy and appears limited, at least in part, by low winter temperatures at higher elevations inland (Mock 1998).

At the northern edge of its range the California Gnatcatcher formerly occurred north to the Los Angeles River watershed (including its major tributary, Tujunga Wash) in Los Angeles County and along the Santa Clara River, which flows southwest from Los Angeles County into Ventura County (Garrett and Dunn 1981). By the time of the listing of subspecies P. c. californica as threatened by the U.S. Fish and Wildlife Service (USFWS) in 1993, it was considered extirpated from Ventura County and most of Los Angeles County (USFWS 1993). However, research on the gnatcatcher increased through the 1990s, and the mobilization of agencies, academic institutions, nonprofit groups, birders, and private consultants has clarified its actual range and promoted its conservation since then. With the adoption of Natural Com- 
munity Conservation Plans (www.wildlife.ca.gov/Conservation/Planning/ NCCP) and similar large-scale, habitat-based planning efforts, over the past 20 years thousands of acres of coastal sage scrub have been preserved as open space throughout southwestern California, and new information on the species continues to be generated through nest monitoring, color banding/ resighting, and hundreds of protocol-level "presence/absence" surveys by USFWS-permitted biologists ("protocol surveys").

Still, considerable confusion exists regarding the historical and current status of the California Gnatcatcher at the northern edge of its range, as attested by inconsistent and sometimes contradictory descriptions of its occurrence there. Away from a "core population" well documented since the mid-1990s in southeastern Ventura County, the situation elsewhere in Ventura County and in neighboring northern Los Angeles County is far less clear. Here we critically evaluate a large number of reports of the California Gnatcatcher from various sources to summarize its historical and current distribution in Ventura and northern Los Angeles County, and offer recommendations for future conservation efforts to protect this vulnerable species at the northern edge of its range.

\section{METHODS}

We defined our study area as including all of Ventura County and the portion of Los Angeles County lying west of Pasadena and north of Santa Monica (California Gnatcatcher populations have been well documented south and east of here for many years; e.g., Cooper 2000, Atwood and Bontrager 2001, www.ebird.org). To identify credible records of the species from this study area, we reviewed museum specimen and egg records (available via www.vertnet.org), published and unpublished studies and checklists, citizen-science efforts including sightings entered at www.ebird. org, and data from local Breeding Bird Surveys (Pardieck et al. 2016) and Christmas Bird Counts (http://netapp.audubon.org/CBCObservation/ Historical/ResultsByCount.aspx\#). We requested and reviewed nearly 250 protocol surveys for the California Gnatcatcher from locations within the study area from the Ventura field office of the USFWS. These surveys involve morning visits, and often broadcast of recordings of calls, to up to 80 acres of suitable habitat per day, repeated at regular intervals over 6 to 18 weeks, depending on the season (USFWS 1997). We also reviewed reports of the species to the California Natural Diversity Database (CNDDB) and all related correspondence obtained via a request to the Ventura field office.

Since the quality of data from these sources varied greatly, critical evaluation was necessary to separate "reports" from "credible records." We accepted all specimen and egg records from museum collections as valid (109 skin/egg specimens; Table 2), as well as any report with an observer and a date accompanied by a photograph, video, sound recording, or a written description that we judged to be credible. In some cases where descriptive details were not included in a report, we attempted to contact the original reporter and obtain details directly. We generally considered positive detections on protocol-level surveys to be valid records; they usually had supporting details, or at least an observer and a date. Since there are no objective, 
universal guidelines for determining the credibility of bird reports (but see Hamilton et al. 2007:39-41), we relied on the experience of the two authors (Cooper and Dellith) who have multiple decades of experience evaluating species reports and conducting field work in the study area.

Accounting for duplicate reports, we compiled a list of 243 protocol surveys and 57 incidental reports from the study area that had been submitted to the USFWS, and reviewed 13 additional reports that had been submitted to the CNDDB. We omitted two CNDDB reports submitted from opposite ends of Santa Clarita on the same date, since the original observer could not remember any details (T. Garrison pers. comm.). We depict results from these protocol surveys and the (valid) CNDDB reports in Figure 1.

We also evaluated more than 200 reports of the California Gnatcatcher from the study area submitted to www.eBird.org through early 2016, finding credible 199 from southeastern Ventura County within areas known to support a consistent population and six from the Los Angeles County portion of the study area. We discounted eBird reports without details that had been submitted from five Ventura County locations (north to Ojai; away from known populations) and from eight Los Angeles County locations (including residential areas). Some of these deleted reports may have been valid, but there was no way of supporting these claims with the available data. We depict all locations of credible eBird records (some with multiple reports) in Figure 2, along with all reports of the similar Blue-gray Gnatcatcher (Polioptila caerulea) from the same area, to illustrate the high level of observer coverage across the study area.

As a rough comparison of survey effort in different portions of the study area, we calculated a single metric, called "survey years," based on the number of protocol surveys for the California Gnatcatcher within a given subregion (Table 1).

In addition to specimen/egg records, we ultimately identified 23 credible reports (as of mid-2016) of the California Gnatcatcher from the Los Angeles County portion of the study area and list these in Table 3. We did not find any credible report of the species in Ventura County away from its known core population (see below). To respect the privacy of both the consultants who submitted the survey data and the clients who paid for these surveys, we do not reference protocol reports by the observer's name or the client company but simply specify the source as "protocol survey" with the dates of sightings, any description, and general location.

\section{DEFINING A NORTHERN RANGE LIMIT}

\section{Ventura County}

The California Gnatcatcher reaches its northern limit along the Pacific coast in Ventura County, as supported by both historical literature (Brewster 1881, Evermann 1886, Cooper 1887) and specimen/egg records. The species formerly occurred north to the city of Ventura and east up the Santa Clara River valley, with collections from the early 1900s at Ventura, Saticoy, and Santa Paula (Table 2). However, following the collection of an egg set at Santa Paula in 1924, now in the Western Foundation of Vertebrate Zoology, Camarillo 
(WFVZ 92163), the California Gnatcatcher went unrecorded in Ventura County until spring 1995, when C. A. Jones discovered a small breeding population in Moorpark during surveys for the "Moorpark Specific Plan \#2" development, in cactus-rich scrub on low hills at the northern terminus of Spring Road (CNDDB). Through the 1990s, however, the California Gnatcatcher was repeatedly referred to as extirpated in Ventura County (e.g., Zeiner et al. 1999, USFWS 2000, Atwood and Bontrager 2001), and later was thought to persist only at the point of its rediscovery in Moorpark (USFWS 2003, 2007). Subsequent protocol surveys in the area, including a directed search of the Moorpark area in 2003 (H. L. Jones unpubl. data), located additional pairs in the surrounding hills that form the border between Moorpark and Simi Valley.

South of Moorpark, the species was apparently first detected along Montclef Ridge northwest of Thousand Oaks in 2008, and southwest to near California State University Channel Islands, on the Oxnard Plain south of Camarillo in 2009 (CNDDB). The eastern edge of the Oxnard Plain may also be considered the extreme western base of the Santa Monica Mountains (see USFWS 2010), but since the California Gnatcatcher has never been found east of there in the remainder of Santa Monica Mountains, we consider that range to still lie outside the species' normal range. Subsequent reports continue to fill in the range, but all recent records appear to be centered in these three roughly contiguous areas: Simi Valley west to Moorpark, the Montclef Ridge area northwest of Thousand Oaks, and the extreme western base of the Santa Monica Mountains near the Oxnard Plain.

The extent to which the California Gnatcatcher occurs in the gaps between these three areas is not well known, as most of the eastern edge of the Oxnard Plain and Montclef Ridge is privately owned and gated, as is the area between Montclef Ridge and Moorpark. However, we assert that this area of southeastern Ventura County, from Simi Valley to the Oxnard Plain, may be considered the "core range" of the California Gnatcatcher in the study area, with multiple nesting birds at various locations found every year over the past decade (see Figure 3; USFWS unpubl. data; eBird).

\section{Northern Los Angeles County}

In neighboring Los Angeles County, the situation is far murkier. With populations historically known from the southern face of the San Gabriel Mountains, the California Gnatcatcher was long thought to reach its interior (noncoastal) northern limit in the San Fernando Valley (Grinnell 1898, Grinnell and Miller 1944), the source of the vast majority of the 100+ specimens from the study area (Table 2). In their comprehensive review of California bird distribution, Grinnell and Miller (1944) did not mention a 1936 egg set from Mint Canyon (WFVZ 92164) or map the species' range north of the San Fernando Valley into Santa Clarita. By the 1970s, Garrett and Dunn (1981) regarded the population in the San Gabriel foothills as "very rare, perhaps extirpated" and omitted the entire interior population from their range map. Later publications (e.g., Atwood 1980) mapped several "occurrences" within the Los Angeles Basin (including Big Tujunga Wash), but did not provide supporting details such as dates, observers, or descriptions of the birds reported. Subsequent publications and technical reports simply repeated these undocumented sightings, leading to the confusion over the species' normal range. 
Table 1 Summary of Protocol-Level Survey Reports for the California Gnatcatcher Submitted to the USFWS from Northwestern Los Angeles County and Ventura County, 1999 to Mid-2016 ${ }^{a}$

\begin{tabular}{|c|c|c|c|c|}
\hline County and subregion ${ }^{b}$ & $\begin{array}{l}\text { Survey } \\
\text { years }^{c}\end{array}$ & $\begin{array}{c}\text { Multiple } \\
\text { individuals in } \\
\text { multiple years }\end{array}$ & $\begin{array}{c}\text { Multiple individuals } \\
\text { in one year or one } \\
\text { individual in multiple } \\
\text { years }\end{array}$ & $\begin{array}{c}\text { Single } \\
\text { individual } \\
\text { observed in } \\
\text { one year }\end{array}$ \\
\hline \multicolumn{5}{|l|}{ Los Angeles } \\
\hline Agoura/Calabasas & 7 & - & - & - \\
\hline Burbank/Glendale & 3 & - & - & - \\
\hline Castaic & 22 & $x$ & - & - \\
\hline Chatsworth & 1 & - & - & - \\
\hline Encino & 1 & - & - & - \\
\hline Malibu & 1 & - & - & - \\
\hline Newhall Ranch & 19 & - & $x$ & - \\
\hline Placerita/Sand Canyon & 23 & $x$ & - & - \\
\hline Granada Hills & 11 & - & - & $x$ \\
\hline Saugus/Newhall & 28 & - & - & - \\
\hline Tujunga/Pacoima & 2 & - & $x$ & - \\
\hline Val Verde & 5 & - & - & $\times$ \\
\hline \multicolumn{5}{|l|}{ Ventura } \\
\hline Camarillo & 3 & - & - & - \\
\hline Grimes Canyon & 5 & - & - & - \\
\hline Moorpark & 15 & $x$ & - & - \\
\hline Newbury Park & 3 & - & - & - \\
\hline Santa Paula & 1 & - & - & - \\
\hline Simi Valley & 33 & $x$ & - & - \\
\hline Somis & 1 & - & - & - \\
\hline Thousand Oaks East & 4 & - & - & - \\
\hline Thousand Oaks West & 5 & $x$ & - & - \\
\hline
\end{tabular}

Incidental observations and those submitted only to the California Natural Diversity Data Base and other sources not included.

b"Subregions" refer to nearest cities, neighborhoods, or geographic landmarks.

'Sum of the total number of protocol-level surveys in each subregion, with multiple years counted as separate surveys.

Following intensive coverage for Los Angeles County's breeding bird atlas in the late 1990s (Allen et al. 2016) and additional field work here through the 2000s (Cooper 2000, eBird), a population in the county's interior was clarified as extending from San Dimas south through the Puente Hills and west to the Montebello Hills. However, no consistent population has been found in recent years in the Pasadena or San Fernando Valley areas to the northwest, nor in the Claremont area to the east, where the California Gnatcatcher also occurred formerly (multiple specimens/egg sets).

North of the species' stronghold on the Palos Verdes Peninsula, through its former range along the coast, recent scattered sightings have been noted north only to the vicinity of Marina del Rey and Culver City (eBird). Multiple birds, including an apparent pair, were photographed nearby in dune scrub at the Los Angeles International Airport in 2013 (eBird). Farther north along the coast, the species is still unknown even as a vagrant from the Los 


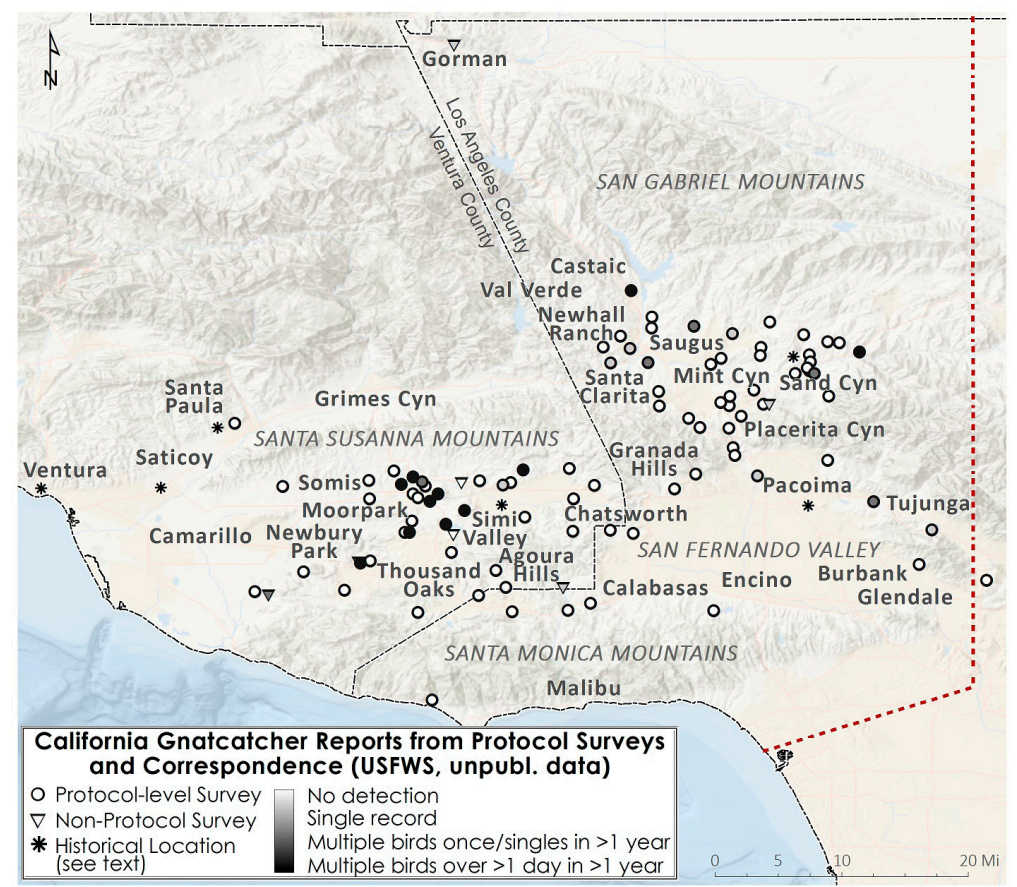

Figure 1. Results of protocol-level surveys and miscellaneous detections of the California Gnatcatcher submitted to the USFWS from Ventura and northwestern Los Angeles counties (USFWS unpubl. data).

Angeles County portion of the Santa Monica Mountains (fide K. L. Garrett). Published references to a California Gnatcatcher population in Santa Clarita (northern Los Angeles County) first appeared as early as 2000 when the area was proposed as critical habitat by the USFWS (2000): "Unit 15 ... includes breeding gnatcatcher populations and sage scrub habitat in the Placerita, Box Springs Canyon, and Plum Canyon areas. This unit encompasses the northern distributional extreme of the gnatcatcher's current range." Later, the USFWS (2003) repeated the reference to "high-quality coastal sage scrub" in "Placerita, Box Springs Canyon, and Plum Canyon" though no indication of California Gnatcatcher nesting had been reported in these canyons, either historically or recently (note: Box Springs Canyon is actually in Riverside County).

Support for the notion that a population of the California Gnatcatcher is resident in Santa Clarita was summarized in 2002 by the late Frank Hovore, a local naturalist, in a letter to the USFWS, in which he listed (without attribution) three single-day sightings in the Placerita-Sand Canyon area, along with several unpublished reports with vague dates and details, presumably from other observers, spanning northwestern Los Angeles County: a "population of undetermined size and status ... in Tujunga Wash," a "single pair" at the 
Table 2 Summary of Specimens of the California Gnatcatcher Collected in Northwestern Los Angeles County and Ventura County ${ }^{a}$

\begin{tabular}{|c|c|c|c|}
\hline County and site & $\begin{array}{c}\text { Total } \\
\text { specimens/eggs }\end{array}$ & $\begin{array}{l}\text { Latest year } \\
\text { collected }\end{array}$ & $\begin{array}{c}\text { Extant population } \\
\text { in vicinity? }\end{array}$ \\
\hline \multicolumn{4}{|l|}{ Los Angeles } \\
\hline Mint Canyon & 1 & 1936 & No \\
\hline San Fernando Valley ${ }^{b}$ & 101 & 1923 & No \\
\hline \multicolumn{4}{|l|}{ Ventura } \\
\hline Santa Paula & 2 & 1924 & No \\
\hline Saticoy $^{c}$ & 1 & 1872 & No \\
\hline Simi Valley & 2 & 1904 & Yes \\
\hline Ventura & 2 & 1906 & No \\
\hline
\end{tabular}

a Museum specimen or egg sets located at the California Academy of Sciences (San Francisco), Chicago Academy of Sciences, Delaware Museum of Natural History (Wilmington), Field Museum of Natural History (Chicago), Natural History Museum of Los Angeles County (Los Angeles), Museum of Vertebrate Zoology (University of California, Berkeley), Ohio State University (Columbus), Royal Ontario Museum (Toronto), San Diego Natural History Museum, University of California (Los Angeles), National Museum of Natural History (Smithsonian Institution, Washington, D.C.), Western Foundation of Vertebrate Zoology (Camarillo, CA), and Yale Peabody Museum (New Haven, CT).

'Includes Garnsey, Lankershim, San Fernando, Toluca, "Tejunga (sic)," (Big) Tujunga Wash, and Tujunga Valley.

cListed at www.vertnet.org as "Saticon," county unspecified.

"“Cascades' development site in Sylmar in 1996," a "single male" in Placerita Canyon in 1973, one nearby at Walker Ranch in "spring in the early 1970s," and "two males (and) one female or juvenile" at Vasquez Rocks in the "late 1970s." While Hovore concluded "these birds must reside somewhere within the Golden Valley Ranch-Sand Canyon axis," there is no evidence they did, at least as a stable population, and these records may just as likely represent individuals dispersing from more distant populations to the southeast. None were accompanied with supporting details or photographs.

By 2007, this same area (Santa Clarita Valley) was regarded as "an essential linkage between the two isolated populations: a core population in the Moorpark area in Ventura County and the pairs documented in the foothills of the San Gabriel Mountains in Los Angeles County" (USFWS 2007), despite Santa Clarita being located well north of a line connecting Ventura County with the San Gabriel Valley birds, and the acknowledgment in the same document that "numerous surveys have been conducted in the Santa Clarita Valley ... but no breeding pairs have been observed." As late as the five-year review of the California Gnatcatcher's status in 2010, the USFWS claimed that "current data indicate gnatcatchers occur in the greater Santa Clarita Valley area (i.e., in the foothills along the upper Santa Clara River)" and depicted the entire Santa Clarita area (along with the San Fernando Valley, Verdugo Hills, and Santa Monica Mountains) as within the "current range" of the species (USFWS 2010: figure 1). Most recently, Allen et al. (2016) referenced "an outlying population in the Santa Clarita River (sic) watershed" during field work for the Los Angeles County breeding bird atlas from 1995 to 2000 . They provided no further details but mapped the species' breeding in that area as "possible" rather than "confirmed." 
Valid, though sporadic, records of California Gnatcatchers continue to accumulate along the western base of the San Gabriel Mountains, mainly from the Big Tujunga Wash and Santa Clarita areas. Most involve single birds, often seen briefly. Multiple records of birds seen for multiple days over more than one year (i.e., suggestive of a small breeding population rather than of transients) have come from two disjunct areas, both near Santa Clarita: the low hills just northwest of Castaic Lagoon (up to three breeding pairs currently, Table 3), and the vicinity of Bee Canyon, a short tributary of the upper Santa Clara River east of Santa Clarita just south of Highway 14 (south of the site of the egg set collected in Mint Canyon in 1936). The birds at Castaic Lagoon were discovered in 2014, while those at Bee Canyon were reported in 2012 as one pair building a nest and another apparent family group feeding four fledglings. The Bee Canyon population is not considered extant, as no California Gnatcatchers were found there during protocol surveys in other years (conducted at least in 2007, 2012, 2015, and 2016; USFWS unpubl. data), though a single-day sighting was made on a protocol survey in 2008, prior to the discovery of breeding (Table 3).

Sightings from the Big Tujunga Wash area have involved mainly single birds, despite extensive coverage from birders (>3000 checklists submitted to eBird as of 2016), Breeding Bird Survey data (Pardieck et al. 2016), and protocol surveys (e.g., Griffith Wildlife Biology 2009). Allen et al. (2016) questioned early reports of the California Gnatcatcher from the Big Tujunga Canyon area on Breeding Bird Surveys, suggesting they pertain to misidentified Blue-gray Gnatcatchers. The lone sighting of more than one bird from the Sunland/Tujunga area involved a male and two birds of unknown age and sex, seen on a single day in September, which could have been dispersing birds (see Table 3).

So, while it is possible a small population may be present along Big Tujunga Wash or in the low hills to the north or south, this has never been confirmed, and the species remains unequivocally rare across northern Los Angeles County. Of $\sim 170$ protocol surveys we reviewed within the Los Angeles County portion of the study area, just 12 had yielded positive detections of the California Gnatcatcher. Of the three Christmas Bird Counts in the Los Angeles County portion of the study area, the California Gnatcatcher has been reported twice on the Malibu count $(1966,1972)$, once on the San Fernando Valley count (1960), and never in Santa Clarita (the counts date to 1947, 1957, and 2003, respectively). Atwood (1980) did not consider the reports from the Malibu count nor two reports from the now defunct Sespe count near Santa Paula, to be credible, and we could find no supporting details for any of these reports.

\section{DISCUSSION}

After a thorough review of California Gnatcatcher records in Ventura and northern Los Angeles County, we suggest that (a) the remaining population in southeastern Ventura County should be considered a disjunct, permanent portion of the species' core range, (b) populations that once occurred in the eastern San Fernando Valley and lower Santa Clara River valley should be considered extirpated but within the normal range of the species, and (c) the 


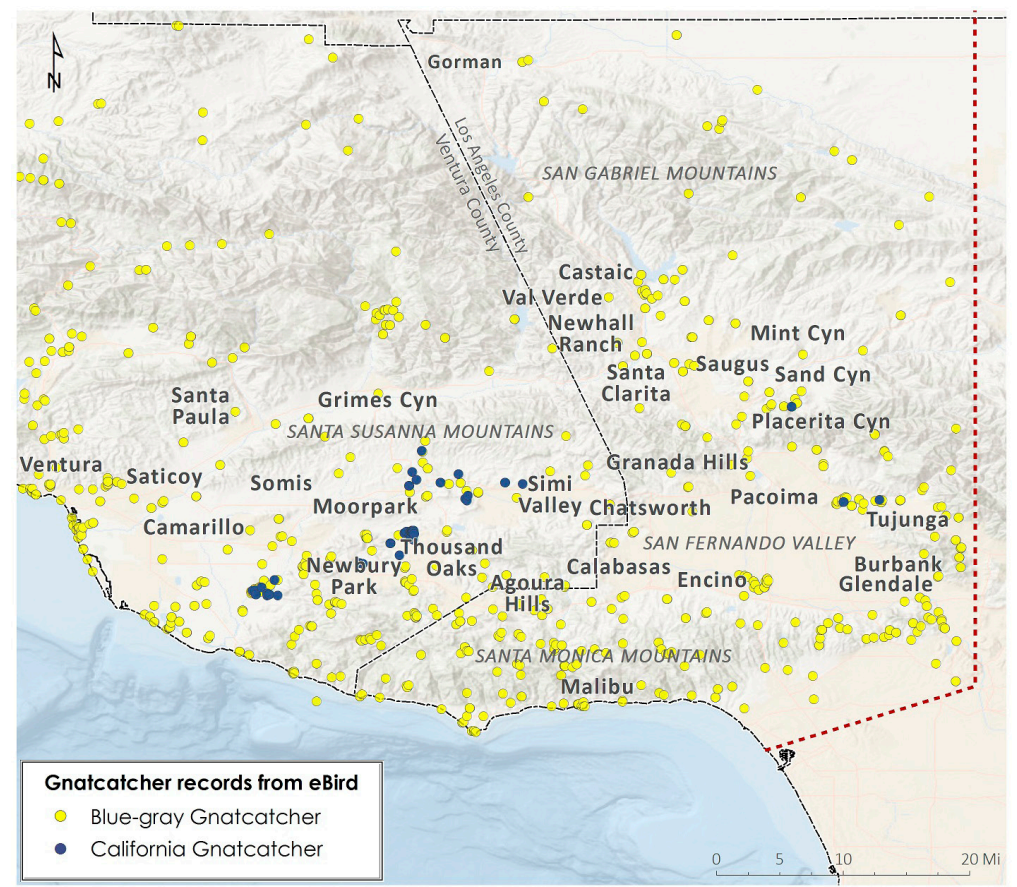

Figure 2. Sites of all reports to www.ebird.org (as of mid-2016) of the Blue-gray Gnatcatcher (yellow) and California Gnatcatcher (blue), Ventura and northwestern Los Angeles counties.

species should be considered marginal and sporadic in the Santa Clarita area until a consistent breeding population is established. We present this new range map as Figure 4. The birds may move around between these areas, but these best capture the main areas of current and historical occurrence. Notably, our proposed range differs substantially from current designations of critical habitat.

This distribution conforms well to Mock's (1998) hypothesis of a limit at an average minimum January temperature of $2.5^{\circ} \mathrm{C}$, in that the Santa Clarita area has an average January low of $2.2^{\circ} \mathrm{C}$ (www.intellicast.com; apparently listed in error as $4^{\circ} \mathrm{C}$ by Mock 1998). Just south of Santa Clarita, in the northeastern San Fernando Valley where the California Gnatcatcher was once common but is now extirpated, the average minimum January temperature is $5.6^{\circ} \mathrm{C}$ in Sun Valley and $4.4^{\circ} \mathrm{C}$ in Sylmar. Near extant populations in Ventura County, average January minimum temperatures range from $4.4^{\circ} \mathrm{C}$ in Simi Valley to $7.2^{\circ} \mathrm{C}$ in both Thousand Oaks and Ventura. Our research offers no new insight on the California Gnatcatcher's absence from the Santa Monica Mountains, which lie between two stable populations (Ventura County and Palos Verdes Peninsula) and seem to have both ample habitat and mild temperatures (average January minimum at Malibu $10.0^{\circ} \mathrm{C}$ ). 


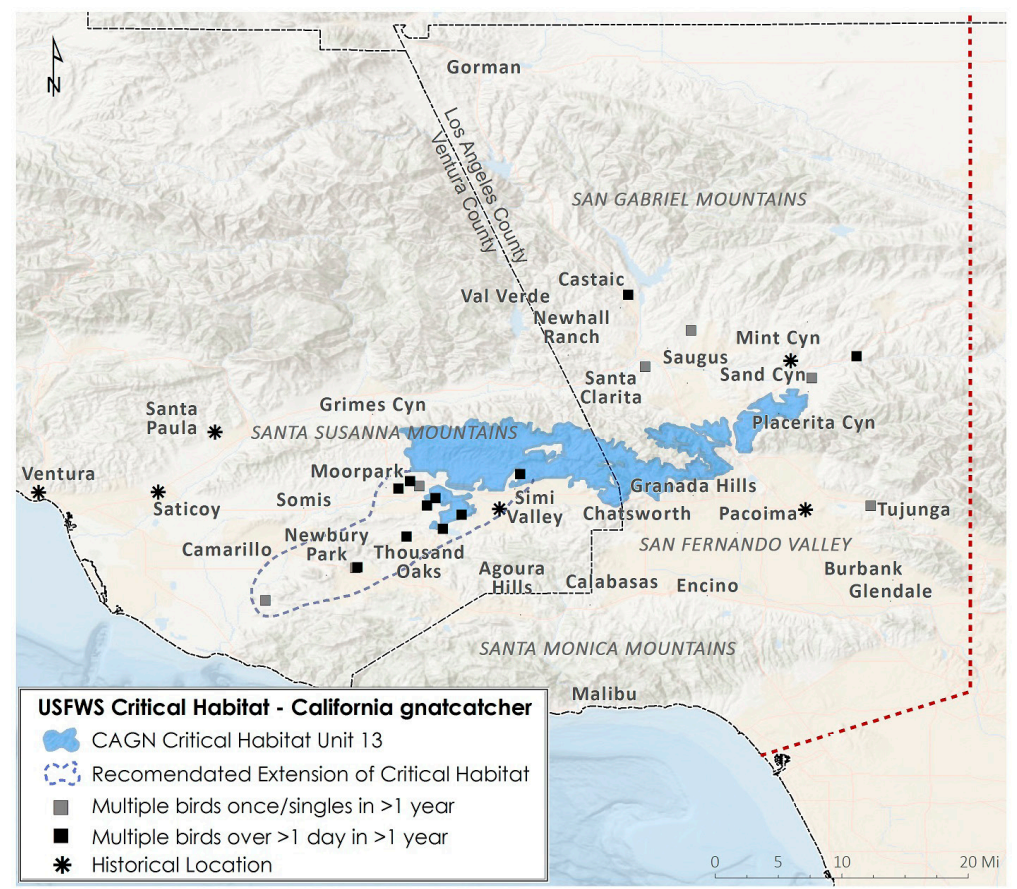

Figure 3. Critical habitat for the California Gnatcatcher as currently designated by the USFWS and as we propose it be modified.

Interpreting isolated records and seasonal movements of the California Gnatcatcher as evidence for extant populations has had several ramifications for the species' conservation. First, it has led to a mismatch between the critical habitat as designated by the USFWS and the gnatcatcher's normal range, isolated occurrences being conflated with areas the species occupies as a permanent resident. This can lead to the species being over-surveyed in habitats where it almost certainly does not occur, while allowing for more development in areas that likely support the species but where limited access has prevented adequate knowledge of its status. For example, not a single California Gnatcatcher has been detected on 28 protocol surveys in the Saugus/Newhall area of Santa Clarita, nor in the Simi Hills or Santa Monica Mountains (Table 1). At the same time, the importance of other areas may be underestimated, including those with documented populations that were affected by recent fires (e.g., Moorpark and Simi Valley), and those where the species has been considered extirpated (e.g., Oxnard Plain).

These are not hypothetical concerns. The current version of critical habitat the USFWS has designated for the California Gnatcatcher within the study area ("Unit 13") misses the majority of remaining pairs in Ventura and northern Los Angeles counties (including those west of Thousand Oaks and the newly discovered breeding birds northwest of Castaic Lagoon). Instead it 


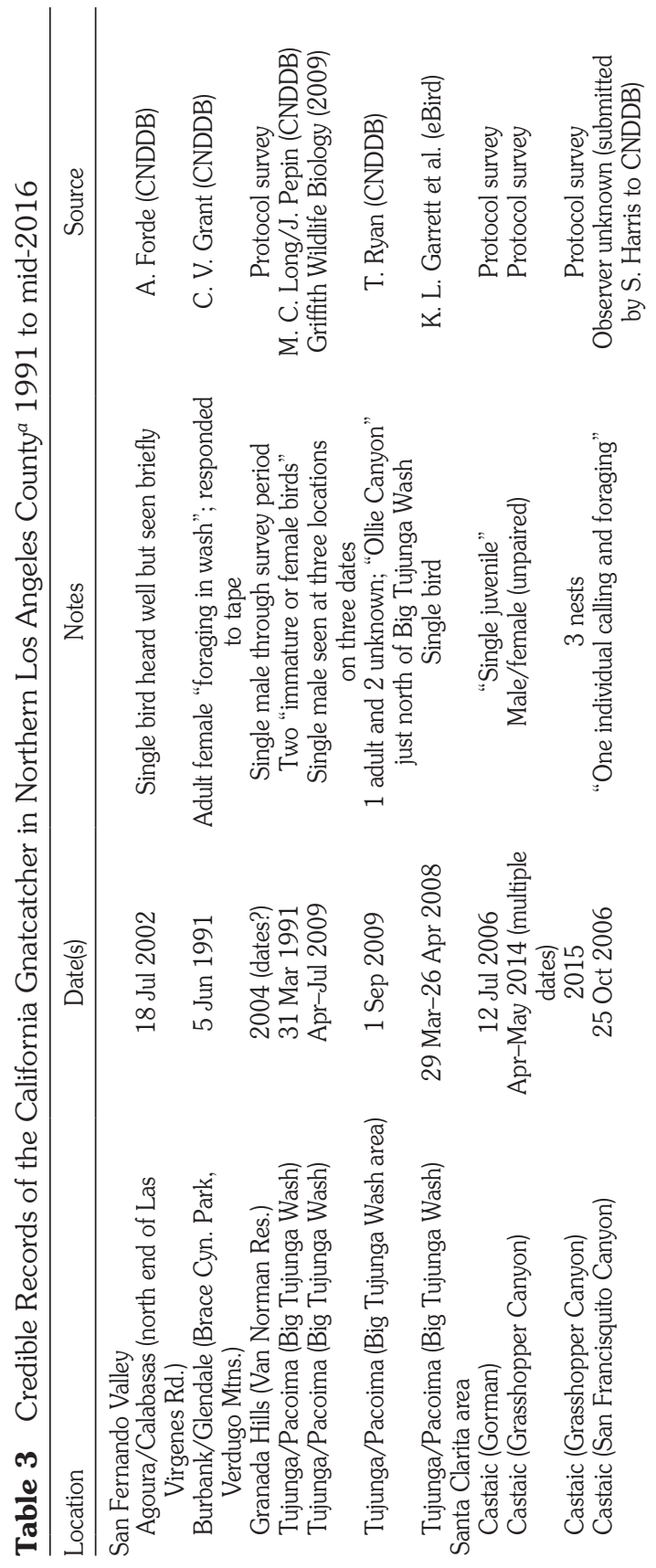




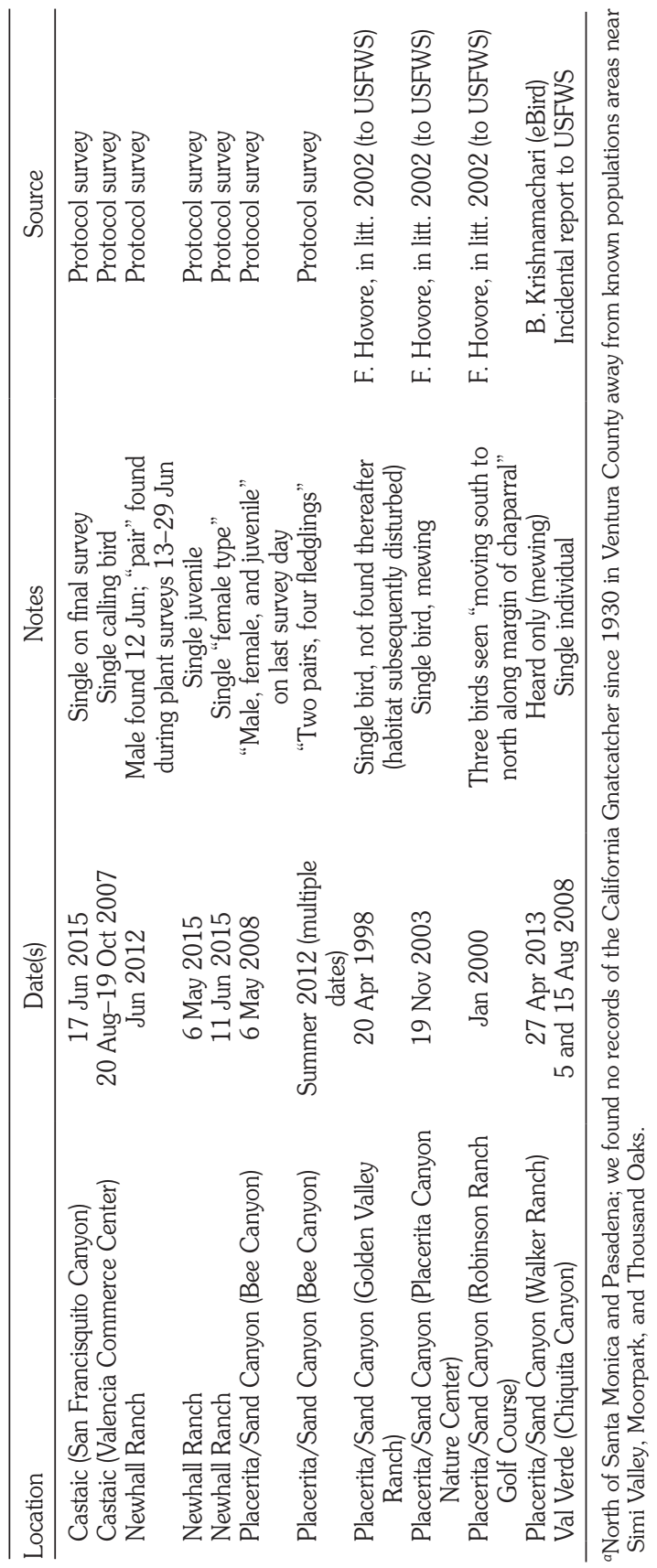




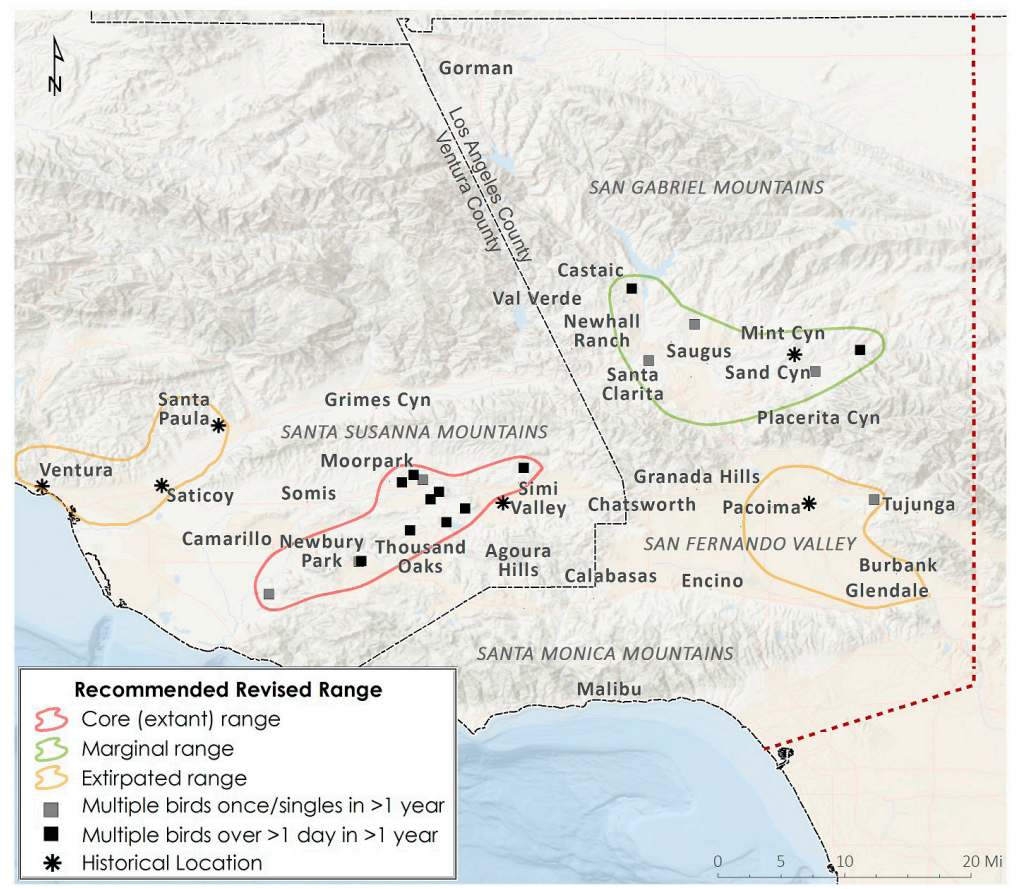

Figure 4. Distribution of the California Gnatcatcher in the northern portion of the range on the basis of a critical reevaluaton of the evidence.

encompasses large areas of the Santa Susana Mountains and southern Santa Clarita dominated by non-native grassland and oak savanna, with patches of chaparral and little coastal sage scrub, that are unlikely to support the species (Figure 3, reproduced from USFWS 2007). An earlier draft of the critical habitat (USFWS 2003) included a larger portion of the habitat near Moorpark, but it was subsequently removed. It is possible the boundaries of Unit 13 were based on incomplete vegetation information and on modeled "potential habitat" (USFWS 2010: figure 3), which has proven problematic here and in subsequent efforts at modeling, as existing vegetation coverage layers do not accurately differentiate between coastal sage scrub and chaparral in Ventura and northwestern Los Angeles counties (K. Preston, USGS, pers. comm.). A more accurate map of critical habitat might extend Unit 13 southwest to include the entire Montclef Ridge/Conejo Grade area from north of Simi Valley southwest through Moorpark and along the eastern edge of the Oxnard Plain (Figure 3).

From our review of current and historical records, we conclude that the California Gnatcatcher has not expanded (permanently) northward or inland into the study area (contra USFWS 2007). Elsewhere in its range, such as in San Diego County, such expansions have been suggested (Vandergast et al. 2014). If anything, the species' Ventura County range has contracted 
away from its far northern edge at Ventura and the lower Santa Clara River valley, toward the southeast (vicinity of Thousand Oaks).

Neither did we find evidence that the species is expanding its range in northern Los Angeles County. Instead, it has been extirpated extensively here, particularly in the San Fernando Valley. To the north and inland, the historical nesting record from Mint Canyon is probably best considered parallel to the ephemeral breeding in 2012 at nearby Bee Canyon-a rare event to be expected near the edge of the normal range of any bird species (the more recent discovery of breeding birds north of Castaic awaits analysis; it may be another ephemeral occurrence, or an actual range extension). Whether these northern Los Angeles County records should be considered indicative of the species' "range" is open to interpretation. An analogous situation, albeit on a larger scale, occurs with many southwestern/Mexican bird species that appear rarely but regularly in southern California, and occasionally even nest, but fail to establish a stable population here, such as the Zone-tailed Hawk (Buteo albonotatus) and Curve-billed Thrasher (Toxostoma curvirostre). These species are typically treated as marginal in the state, with California not part of their normal or consistent range (see Hamilton et al. 2007).

Away from the core Ventura County population, which appears to be genetically isolated from populations farther south (Vandergast et al. 2014), most recent records of the California Gnatcatcher are more consistent with dispersing birds rather than with residents. Even the one-day observation of a single bird at Gorman (Table 3), which seems to defy all patterns of known distribution, actually conforms to this trajectory of scattered birds appearing, mainly in summer and fall after breeding, along the foothills northwest of the San Gabriel Valley.

Still, California Gnatcatcher populations are likely in some flux, particularly at the edges of the range. While the species has long been considered sedentary and nonmigratory (see citations in Atwood and Bontrager 2001), shifts in range have been suspected for over a century, with Willett (1912:106) observing, "it is common in certain parts of Los Angeles County at the present time where it was not noted at all a few years back." As suggested by Bailey and Mock (1998), research into dispersal likely suffers from a bias toward underestimation, since studies tend to attempt to relocate banded birds within nearby habitat and patches, and not in "open populations" far from the site of initial banding. Bailey and Mock also noted the California Gnatcatcher's ability to traverse urban areas ("highly man-modified landscapes"). So, although for most truly sedentary species (such as a reptile or a small mammal), a single occurrence record implies a resident population, the accumulation of extralimital sightings of the California Gnatcatcher may instead represent an underappreciated complexity involving post-breeding dispersal of both adults and juveniles (possibly as pairs or family groups), "pioneering" individuals (including pairs) appearing well away from known populations throughout the year, and sporadic, opportunistic nesting in outlying areas not known to support stable populations.

Additional surveys are urgently needed throughout the study area if we are to understand the true boundaries of the northern populations of the California Gnatcatcher, and to devise conservation strategies to maintain 
them. This will be a challenge, since in contrast to areas farther south where large areas of coastal sage scrub are protected in parks and reserves, suitable habitat in Ventura County and around Santa Clarita and Big Tujunga Wash lies within a patchwork of land owned mostly by private ranches, estates, and homeowners' associations, with comparatively little managed for biodiversity as public open space (Cooper et al. 2012, 2014). Within the gnatcatcher's historical range in the Santa Clara River valley from Ventura to Santa Paula, both north and south of Highway 126, the large fraction in private ownership (much currently being cleared for agriculture and development) also limits public knowledge of the area's avifauna. Nevertheless, recent surveys by The Nature Conservancy at numerous sites along the Santa Clara River have not detected the species (A. Searcy, unpubl. data).

Except in rare cases, the current survey protocol specified by the USFWS is designed simply to detect the gnatcatcher's presence (or support its absence) in advance of a potentially disruptive development, rather than to ascertain its breeding status or population size. Like many surveys for sensitive species, those for the California Gnatcatcher tend to be concentrated at the "leading edge" of urban development, rather than spread comprehensively within the possible habitat. This results in the potential for both undercounting (if a larger population lies just outside a survey boundary) and overcounting (where a single record is interpreted as representing a population), rather than an accurate census from systematic rangewide surveys. To counter this, we recommend immediate surveys and, where feasible, targeted conservation of habitat in eastern Ventura County in such areas as the southwestern Santa Susana Mountains north of Simi Valley and Moorpark, the Tierra Rejada and Santa Rosa valleys, the Montclef Ridge area, and the western base Santa Monica Mountains (edge of the Oxnard Plain) to capture areas of highest usage by the California Gnatcatcher most effectively. Lowerpriority areas that might support dispersing individuals, and that may support populations in the future, should be those away from core populations that are still producing scattered records, including scrub at low elevations $(<1500$ feet) in the southern Santa Susana Mountains, the Santa Clarita area, and around the edge of the San Fernando Valley. On the basis of our experience and recent observations, key areas for investigation here include the low hills east of Castaic Creek (e.g., Charlie and Tapia canyons), those surrounding Castaic Lagoon, lands on either side of the Santa Clara River west of Santa Clarita (e.g., Newhall Ranch, Chiquito Creek), and low hills and washes in the northeastern San Fernando Valley (e.g., Pacoima Wash, Big Tujunga Wash).

To retain intact coastal sage scrub where it remains, we recommend revising requirements for brush clearance, weed abatement, and other techniques for fire control within the core northern range of the California Gnatcatcher, and ending the practice of clearing 200-foot swaths around houses and outbuildings, as these simply become invaded by non-native grasses and actually increase the risk of ignition and accelerate habitat loss. Reviving a regional conservation plan for birds in southeastern Ventura County would be a logical step. An attempt at a Moorpark Habitat Conservation Plan (USFWS 2002) was abandoned in the early 2000s after a major fire and never restarted. Reinstituting this plan would encourage local municipalities such as Simi 
Valley, Moorpark, Thousand Oaks, and Camarillo to prioritize coastal sage scrub conservation within an area also rich in endemic flora. If local agencies ensure that each proposal for new development in eastern Ventura County be accompanied by a protocol-level survey for the California Gnatcatcher, our knowledge of the species' local range and needs would grow. Finally, given the number of unsubstantiated reports outside the known population in the study area, including several entered into government agencies' records via protocol-level survey reports and the CNDDB, we urge that observers fully document any sightings and potential nesting activity in the study area through voice recordings, video, photographs, and thorough field notes, and that they make these observations public (e.g., via www.eBird.org) where possible to allow for critical evaluation of sightings (see Patten et al. 1995).

\section{ACKNOWLEDGMENTS}

We thank Mike Couffer and H. Lee Jones for unpublished notes on California Gnatcatchers in Santa Clarita and Ventura County, respectively. Kimball Garrett (Natural History Museum of Los Angeles County) and Jeremiah Trimble (Museum of Comparative Zoology, Cambridge, Massachusetts) helped clarify detail on early records, and Salvador Contreras assisted with mapping. Kristine Preston, Daniel Ruthrauff, and Philip Unitt provided detailed and extremely helpful comments on an earlier draft, which greatly improved the manuscript. The findings and conclusions in this article do not necessarily represent the views of the U.S. Fish and Wildlife Service. The use of trade names does not imply endorsement by the U.S. federal government.

\section{LITERATURE CITED}

Allen, L. W., Garrett, K. L., and Wimer, M. C. 2016. Los Angeles County Breeding Bird Atlas. Los Angeles Audubon Soc., Los Angeles.

Atwood, J. L. 1980. The United States distribution of the California Black-tailed Gnatcatcher. W. Birds 11:65-78.

Atwood, J. L., and Bontrager, D. R. 2001. California Gnatcatcher (Polioptila californica), in The Birds of North America (A. Poole and F. Gill, eds.), no. 574. Birds N. Am., Philadelphia; doi 10.2173/bna.574.

Bailey, E. A., and Mock, P. J. 1998. Dispersal capability of the California Gnatcatcher: A landscape analysis of distributional data. W. Birds 29:351-360.

Brewster, W. 1881. On the affinities of certain Polioptilae, with a description of a new species. Bull. Nuttall Ornithol. Club. 6:101-107.

Cooper, D. S. 2000. Breeding landbirds of a highly threatened open space: The Puente-Chino Hills, California. W. Birds 31:213-234.

Cooper, D. S., Hamilton, R. A., and Lucas, S. D. 2012. A population census of the Cactus Wren in coastal Los Angeles County. W. Birds 43:151-163.

Cooper, D. S., Hall, L. S., and Searcy, A. J. 2014. A population census of the Cactus Wren in Ventura County, California. W. Birds 45:43-56.

Cooper, J. G. 1887. Additions to the birds of Ventura County, California. Auk 4:85-94; doi 10.2307/4067105.

Evermann, B. W. 1886. A list of the birds observed in Ventura County, California. Auk 3:86-94, 179-186; doi 10.2307/4625337.

Garrett, K., and Dunn, J. 1981. Birds of Southern California: Status and Distribution. Los Angeles Audubon Soc., Los Angeles.

Griffith Wildlife Biology. 2009. The status of the Least Bell's Vireo and Southwestern 
Willow Flycatcher at Los Angeles County drainage area sites in 2009. Report to U.S. Army Corps of Engineers, Los Angeles Operations Branch; available from U.S. Fish and Wildlife Service, 2493 Portola Rd., Suite B, Ventura, CA 93003.

Grinnell, J. 1898. Birds of the Pacific slope of Los Angeles County. Pasadena Acad. Sci. Publ. 11.

Grinnell, J., and Miller, A. 1944. The distribution of the birds of California. Pac. Coast Avifauna 27.

Hamilton, R. A., Patten, M. A., and Erickson, R. A. (eds.). 2007. Rare Birds of California. W. Field Ornithol., Camarillo, CA.

Mock, P. J. 1998. Energetic constraints to the distribution and abundance of the California Gnatcatcher. W. Birds 29:413-320.

Pardieck, K. L., Ziolkowski, D. J. Jr., Hudson, M.-A. R., and Campbell, K. 2016. North American Breeding Bird Survey dataset 1966-2015, version 2015.0. U.S. Geol. Survey, Patuxent Wildlife Research Center; www.pwrc.usgs.gov/BBS/ RawData/.

Patten, M. A., Unitt, P., Erickson, R. A., and Campbell, K. F. 1995. Fifty years since Grinnell and Miller: Where is California ornithology headed? W. Birds 26:54-64.

Rotenberry, J. T., and Scott, T. A. 1998. Biology of the California Gnatcatcher: Filling in the gaps. W. Birds 29:237-241.

USFWS. 1993. Endangered and threatened wildlife and plants; Determination of threatened status for the coastal California Gnatcatcher. Federal Register 58(59): 16741-16757.

USFWS. 1997. Coastal California Gnatcatcher (Poliptila californica californica) presence/absence survey guidelines; www.fws.gov/pacific/ecoservices/endangered/ recovery/documents/CCalGnatcatcher.1997.protocol.pdf

USFWS. 2000. Endangered and threatened wildlife and plants; proposed determination of critical habitat for the Coastal California Gnatcatcher; proposed rule. Federal Register 65(25):5946-5976.

USFWS. 2002. Moorpark Highlands Habitat Conservation Plan, Ventura County, CA. Federal Register 67(17):3731.

USFWS. 2003. Endangered and threatened wildlife and plants; designation of critical habitat for the Coastal California Gnatcatcher (Polioptila californica californica) and determination of distinct vertebrate population segment for the California Gnatcatcher (Polioptila californica); proposed rule. Federal Register 68(79):20228-20312.

USFWS. 2007. Endangered and threatened wildlife and plants; revised designation of critical habitat for the Coastal California Gnatcatcher (Polioptila californica californica); final rule. Federal Register 72(243):72010-72213.

USFWS. 2010. Coastal California gnatcatcher (Polioptila californica californica), 5-year review: Summary and evaluation; www.fws.gov/carlsbad/SpeciesStatus List/5YR/20100929_5YR_CAGN.pdf

Vandergast, A. G., Kus, B. E., Barr, K. R., and Preston, K. L. 2014. Genetic structure in the California Gnatcatcher in coastal southern California and implications for monitoring and management. Report to Calif. Dept. Fish and Wildlife, Sacramento; https://nrm.dfg.ca.gov/FileHandler.ashx?DocumentID=97711.

Willett, G. 1912. Birds of the Pacific slope of southern California. Pac. Coast Avifauna. 7.

Zeiner, D. C., Laudenslayer, W. F. Jr., Mayer, K. E., and White, M. (eds.). 1999. California's Wildlife, vol. II: Birds. Calif. Dept. Fish and Game, Sacramento.

Accepted 9 March 2017 